\title{
Heavy metal concentrations in the different tissues of horseshoe crabs collected from intertidal sites of the polluted Juru River and the relatively unpolluted Sepang Besar River, Peninsular Malaysia
}

\author{
${ }^{1}$ Yap*, C. K., ${ }^{1}$ Mohd Ruszaidi, S., ${ }^{1}$ Edward, F. B. and ${ }^{2}$ Tan, S. G. \\ ${ }^{1}$ Department of Biology, Faculty of Science, \\ ${ }^{2}$ Department of Cell and Molecular Biology, Faculty of Biotechnology and Biomolecular Sciences, \\ Universiti Putra Malaysia, 43400 UPM, Serdang, Selangor, Malaysia. \\ *yapckong@ hotmail.com (Corresponding author) Tel: 603-89466616, Fax: 603-86567454 \\ Received on $16^{\text {th }}$ April 2009, accepted in revised form 14th July 2010.
}

\begin{abstract}
Horseshoe crabs (Tachypleus gigas) were collected from intertidal sites of the polluted Juru River (Penang) and the relatively unpolluted Sepang Besar River (Selangor) in September and December 2007. They were dissected into six parts namely carapace, muscle, telson, leg, operculum and gills. For each site, different tissues from the horseshoe crabs were determined for the concentrations of $\mathrm{Cd}, \mathrm{Cu}, \mathrm{Ni}, \mathrm{Fe}, \mathrm{Pb}$ and $\mathrm{Zn}$ in them. Gills accumulated the highest concentrations of $\mathrm{Cu}, \mathrm{Cd}, \mathrm{Fe}, \mathrm{Ni}$ and $\mathrm{Pb}$. Muscles were found to have the highest concentrations of $\mathrm{Zn}$. Most distinctively, the concentrations of $\mathrm{Cu}, \mathrm{Ni}$ and $\mathrm{Zn}$ in the muscles of the Juru River population were significantly $(\mathrm{P}<0.05)$ higher than those from the Sepang Besar River, indicating that the Juru River had higher contaminations and bioavailabilities of these metals than the Sepang Besar River. This conclusion was also well supported by the sediment data. These results suggest that $T$. gigas (especially the muscle) is a potential biomonitor of $\mathrm{Cu}, \mathrm{Ni}$ and $\mathrm{Zn}$ contaminations and bioavailabilities in tropical intertidal areas.
\end{abstract}

(Keywords: Horseshoe crab, Tachypleus gigas, Heavy metals, Peninsular Malaysia)

\section{INTRODUCTION}

Horseshoe crab, Tachypleus gigas (Family: Limulidae) is a marine chelicerate arthropod. The animal has a body divided into two main subdivisions, the prosoma (head) and the opisthosoma. There are four species of living horseshoe crabs in the world which are similar in terms of ecology, morphology, and serology [1]. Three of the world's four species are found in Asia while Limulus polyphemus occurs on the east coast of the United States of America [2], especially at Delaware Bay.

All the four horseshoe crab species are now considered as being under threat. In Asia, T. gigas, T. tridentatus and Carcinoscorpius rotundicauda are consumed. Their eggs are regarded as a delicacy, for example in Singapore, Malaysia, Borneo [3], Thailand [4], Hong Kong and China [5].

Horseshoe crabs are benthic or bottom dwelling arthropods that use both estuarine and continental shelf habitats. They inhabit shallow marine waters, generally on sandy bottoms where they move about or burrow just beneath the surface, preying on other animals. Since horseshoe crabs deposit and fertilize eggs in the sand, their eggs serve as a food source for shorebirds. Therefore, their ecological characteristics are of much concern from the ecotoxicological point of view.

Elsewhere in the world, horseshoe crab populations have been reported to be in decline, with the major causal factors being loss of spawning and nursery habitats and over harvesting for food, fertilizers, and fish baits in locations such as Thailand [6].

Besides, horseshoe crabs are diets of shorebirds that feed on them during their migration [7]. Therefore, their consumption by humans and migratory birds are two major concerns why their metal concentrations need to be determined. Many studies were done to determine the metal levels in horseshoe crabs and their effects on the development of the embryos of horseshoe crabs [813]. However, similar studies from Malaysia are still very limited in the literature.

The objective of this study was to determine the heavy metal concentrations $(\mathrm{Cd}, \mathrm{Cu}, \mathrm{Fe}, \mathrm{Ni}, \mathrm{Pb}$ and $\mathrm{Zn}$ ) in the different tissues of $T$. gigas collected from polluted and relatively unpolluted intertidal sites in Peninsular Malaysia. 


\section{MATERIALS AND METHODS}

Samplings of horseshoe crabs and sediments were conducted in the intertidal areas of the Juru River and the Sepang Besar River of Peninsular Malaysia between September and December 2007 (Figure 1). The sampling conditions and site descriptions are given in Table 2. The samples were then stored in an ice container at $10^{\circ} \mathrm{C}$ until transportation to the UPM laboratory. In the laboratory, the horseshoe crabs were measured for total wet weight, length, width and height and these measurements are shown in Table 1.
Then, the males and the females were carefully dissected into different parts namely carapace, muscle, leg, operculum, gill, and telson. Eggs of the individual females were also dissected for metal analysis. For each site, the dissected individual parts were pooled and placed in aluminum foils and then were dried in the oven for 72 hours at $105^{\circ} \mathrm{C}$ to constant dry weights [14]. The analytical procedures for the sediment followed those described by Yap et al. [15].

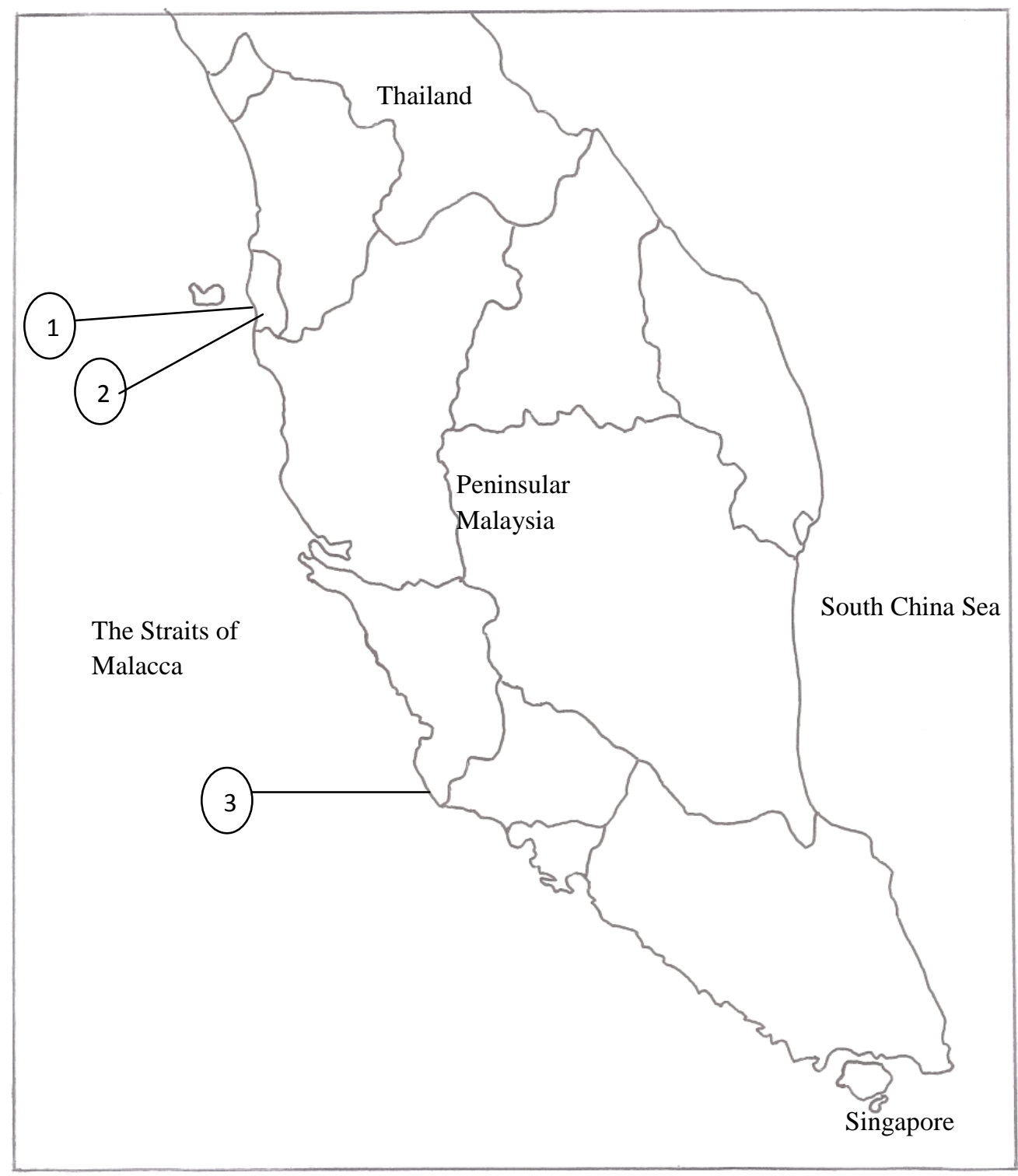

Figure 1: Map showing sampling sites in the Juru River and the Sepang Besar River, Peninsular Malaysia [Note: (1) Juru River 1; (2) Juru River 2; (3) Sepang Besar River] 
The dried tissues of the horseshoe crabs were digested in concentrated nitric acid (AnalaR grade, BDH $69 \%$ ) by placing them in a hot-block digester, first at low temperature for one hour and then they were fully digested at high temperature $\left(140^{\circ} \mathrm{C}\right)$ for at least three hours. The digested samples were then diluted to $40 \mathrm{~mL}$ with double distilled water.

After filtration, the samples were determined for the $\mathrm{Cd}, \mathrm{Cu}, \mathrm{Fe}, \mathrm{Ni}, \mathrm{Pb}$ and $\mathrm{Zn}$ concentrations by using an air-acetylene flame Atomic Absorption Spectrophotometer (AAS) Perkin-Elmer Model AAnalyst 800 . The data were presented in $\mu \mathrm{g} / \mathrm{g}$ dry weight basis.

To avoid possible contamination, all the glassware and equipment used were acid-washed and the accuracy of the analysis was checked with the blanks and quality control samples made up of standard solutions. The analytical procedures for the horseshoe crabs were checked with the Certified Reference Material (CRM) for dogfish liver (DOLT-3, National Research Council Canada) and the recoveries of all the metals were satisfactory (Table 3).

\section{RESULTS AND DICUSSION}

From Tables 4-9 it is noteworthy to see that the concentrations of $\mathrm{Cd}$ (Table 4), $\mathrm{Cu}$ (Table 5), $\mathrm{Fe}$ (Table 6), Ni (Table 7), Pb (Table 8) and Zn (Table 9) were higher in the muscles of the Juru population (in either Juru-1 or Juru-2) than in those from the Sepang Besar River. This finding is well supported by the sediment data (Table 10) in which the concentrations of $\mathrm{Cu}, \mathrm{Ni}$ and $\mathrm{Zn}$ in the surface sediments were significantly higher $(\mathrm{P}<0.05)$ in the Juru River than in the Sepang Besar River.

The muscle is a more reliable tissue for biomonitoring of heavy metal bioavailability and contamination when compared to the gills, carapace, legs, telson and operculum in that these tissues are more exposed to the external ambient environment. Also, the muscle is less affected by physiological conditions such as fatty acid levels and merging with eggs. The muscle is a solid tissue with a high protein content which can better reflect the accumulation of heavy metals by the horseshoe crabs.

From Tables 4-9 again, it is found that the higher metal levels are usually found in the gills when compared to the other parts. For $\mathrm{Cu}$ and $\mathrm{Pb}$, the concentrations in the gill ranged from 93.81$240.29 \mu \mathrm{g} / \mathrm{g} \mathrm{dw}$ and 10.36-17.44 $\mu \mathrm{g} / \mathrm{g} \mathrm{dw}$, respectively. Kannan et al. [8] reported that the concentrations of $\mathrm{Fe}$ and $\mathrm{Pb}$ were highest in the gill.

$\mathrm{Fe}$ in the operculum also showed a similar pattern of accumulation as the gill, with the highest accumulation at all the sites. Fe accumulation in the operculum ranged from 244.47- $435.57 \mu \mathrm{g} / \mathrm{g} \mathrm{dw}$. James [16] reported that $\mathrm{Fe}$ is an essential metal for oxygen transport in the blood of some invertebrates.

Muscles were highly accumulative of $\mathrm{Zn}$ and $\mathrm{Cu}$. Muscles from male individuals in Juru River 2 showed the highest accumulation of $\mathrm{Cu}$ (137.86 $\mu \mathrm{g} / \mathrm{g} \mathrm{dw}$ ) whereas the horseshoe crab in the Sepang Besar River showed the lowest $\mathrm{Cu}$ concentration (38.23 $\mu \mathrm{g} / \mathrm{g} \mathrm{dw})$. These differences indicated that the Juru River was more polluted than the Sepang Besar River and this is in agreement with the most recent Malaysian Department of Environment report

[17].

Muscle was studied because it is important to know the metal levels in this tissues since horseshoe crabs are consumed by the local human populations [18]. From the literature, Burger [19] reported that the level of $\mathrm{Pb}$ was significantly lower in the muscle while Kannan et al. [8] reported that the $\mathrm{Zn}$ concentration was higher in the muscle.

In particular, the heavy metal concentrations in the muscles and eggs of horseshoe crabs are of much interest for three reasons: 1) as a biomonitor of metal levels in intertidal areas, 2) as an indicator of potential problems for developing horseshoe crabs, and 3 ) as food sources of migratory shorebirds [20].

According to Peakall [21] and recent literature, increasingly reports are using marine organisms as indicators (whether bioindicators or biomonitors) of environmental contamination. According to Burger [19], the levels of heavy metals in horseshoe crab eggs should be relatively low because the crabs are low in the food chain. This is in agreement with the present findings.

The metal levels accumulated in the horseshoe crabs can come from two sources: 1) sequestration by the female during egg formation, and 2) from the surrounding water. Since in birds, heavy metals are sequestered in eggs [22,7], it is not surprising that they would be sequestered in the eggs of invertebrates as well. Burger 's [19] finding that the mean concentrations of $\mathrm{Cd}$ and $\mathrm{Pb}$ in the muscles of female Limulus polyphemus collected from the Delaware Bay were all below those of the eggs, was indicative of some possible adverse effects 
Table 1: Allometric data for Tachypleus gigas collected from the Juru River and the Sepang Besar River.

\begin{tabular}{|c|c|c|c|c|c|c|}
\hline Site & Sex & $\mathrm{N}$ & $\begin{array}{l}\text { Total wet weight } \\
\text { (g) }\end{array}$ & Length (cm) & Width $(\mathrm{cm})$ & Height $(\mathrm{cm})$ \\
\hline \multirow[t]{3}{*}{ Juru River-1 } & Male & 4 & $71.42 \pm 12.26$ & $24.70 \pm 0.64$ & $10.89 \pm 0.51$ & $3.18 \pm 0.11$ \\
\hline & & & $(46.56-103.86)$ & $(23.26-26.36)$ & $(10.12-12.41)$ & (2.94-3.48) \\
\hline & Female & 1 & 149.35 & 35.84 & 13.26 & 4.71 \\
\hline \multirow[t]{4}{*}{ Juru River-2 } & Male & 3 & $106.73 \pm 12.80$ & $29.16 \pm 0.48$ & $11.71 \pm 0.18$ & $3.31 \pm 0.42$ \\
\hline & & & $(82.96-126.84)$ & $(28.24-29.85)$ & (11.52-12.07) & $(2.68-4.12)$ \\
\hline & Female & 2 & $187.75 \pm 16.39$ & $37.42 \pm 2.96$ & $13.61 \pm 0.36$ & $4.80 \pm 0.34$ \\
\hline & & & (171.36-204.14) & (34.46-40.38) & $(13.25-13.97)$ & $(4.46-5.14)$ \\
\hline Sepang & Female & 2 & $687.80 \pm 60.33$ & $44.68 \pm 1.07$ & $16.28 \pm 0.09$ & $7.44 \pm 0.09$ \\
\hline \multicolumn{7}{|l|}{ Besar River } \\
\hline & & & $(627.47-748.14)$ & $(43.61-45.75)$ & $(16.19-16.37)$ & $(7.35-7.53)$ \\
\hline
\end{tabular}

Note:

Length was measured from anterior carapace (prosoma) to the posterior telson;

Width was measured from tip of right carapace (prosoma) to the tip of left carapace (prosoma); Height was measured from top carapace to the bottom carapace. 
Table 2: Site description and sampling conditions for the horseshoe crabs.

\begin{tabular}{|c|c|c|c|}
\hline & Sepang Besar River & Juru River 2 & Juru River 1 \\
\hline \multirow[t]{2}{*}{ GPS reading } & $02^{\circ} 36.042^{\prime} \mathrm{N}$ & $5^{\circ} 35.096^{\prime} \mathrm{N}$ & $5^{\circ} 35.096^{\prime}$ \\
\hline & $101^{\circ} 42.461^{\prime} \mathrm{E}$ & $100^{\circ} 37.307^{\prime} \mathrm{E}$ & $\mathrm{N} 100^{\circ} 37.307^{\prime} \mathrm{E}$ \\
\hline Date of sampling & 1 Dec 2007 & 8 Dec 2007 & 10 Sep 2007 \\
\hline Time of sampling & $11.15-11.30 \mathrm{am}$ & 10.30am - 11.05am & NA \\
\hline Weather & $\begin{array}{l}\text { Hot and a little bit } \\
\text { windy }\end{array}$ & sunny and bright day & NA \\
\hline Site description & $\begin{array}{l}\text { An ex-pig farming } \\
\text { area }\end{array}$ & $\begin{array}{l}\text { The well-known Juru } \\
\text { Industrial Area in the } \\
\text { upstream }\end{array}$ & $\begin{array}{l}\text { The well-known Juru } \\
\text { Industrial Area in the } \\
\text { upstream }\end{array}$ \\
\hline Water temperature & 27.87 & NA & NA \\
\hline Conductivity $(\mu \mathrm{s} / \mathrm{cm})$ & 36677.2 & NA & NA \\
\hline TDS (g/L) & 22.6 & NA & NA \\
\hline Water salinity (ppt) & 21.79 & NA & NA \\
\hline
\end{tabular}

NA: Data are not available.

Table 3: Comparison of metal concentrations $(\mu \mathrm{g} / \mathrm{g}$ dry weight) between measured and their certified values of the certified reference materials (CRMs)-DOLT-3 Dogfish-liver.

\begin{tabular}{|c|c|c|c|}
\hline Metals & CRM values $(\mathrm{C})$ & Measures values (M) & Percentage $\%$ of recovery $(\mathrm{M} / \mathrm{C})$ \\
\hline $\mathrm{Cd}$ & $19.4 \pm 0.600$ & $20.5 \pm 0.439$ & $106 \pm 2.26$ \\
\hline $\mathrm{Cu}$ & $31.2 \pm 1.00$ & $26.5 \pm 2.58$ & $85.0 \pm 8.28$ \\
\hline $\mathrm{Fe}$ & $1484 \pm 57.0$ & 1070 & 72.1 \\
\hline $\mathrm{Ni}$ & $2.72 \pm 0.350$ & $2.77 \pm 0.741$ & $102 \pm 27.2$ \\
\hline $\mathrm{Zn}$ & $86.6 \pm 2.40$ & $80.9 \pm 1.94$ & $93.4 \pm 2.24$ \\
\hline
\end{tabular}


However, the present findings that all the metal levels in the horseshoe crabs eggs were higher than those in the muscles might indicate the possibility of much more adverse effects. Therefore, further studies are needed to investigate this problem. There are very limited published data on heavy metals in horseshoe crabs.

For example, Burger [19] reported that mean concentrations of $\mathrm{Cd}$ and $\mathrm{Pb}$ in the muscles of female Limulus polyphemus collected from the Delaware Bay were $0.021 \mu \mathrm{g} / \mathrm{g}$ wet weight for $\mathrm{Pb}$ and $0.013 \mu \mathrm{g} / \mathrm{g}$ wet weight for $\mathrm{Cd}$.

However, for comparative purposes, the metal concentrations $(\mu \mathrm{g} / \mathrm{g}$ dry weight) in the muscle of the green-lipped mussel Perna viridis collected from the Straits of Johore [23] averaged 89.8 for $\mathrm{Fe}, 16.1$ for $\mathrm{Ni}, 1.43$ for $\mathrm{Cd}, 6.98$ for $\mathrm{Cu}, 10.2$ for $\mathrm{Pb}$ and 77.3 for $\mathrm{Zn}$.

In general, these metal concentrations are comparable and similar to the concentrations of three non-essential metals, $\mathrm{Cd}, \mathrm{Ni}$ and $\mathrm{Pb}$ in the muscle of $T$. gigas while the essential metals, $\mathrm{Cu}$, $\mathrm{Fe}$ and $\mathrm{Zn}$ are found at comparatively higher levels in the muscles of $T$. gigas when compared to the muscles of $P$. viridis.

The relatively high concentrations of the same metals in horseshoe crab eggs suggest that shorebirds are acquiring metals from these or other invertebrates, and may be storing them in their bodies for later mobilization and sequestration in their feathers. Overall, the levels of heavy metals in the muscles of horseshoe crab females were comparatively low.

Carapace was also examined in this study since there were reports in some organisms that metals are sequestered in the skin or eggshells as a method of metal excretion [24-25]. Generally, the burden of heavy metals such as $\mathrm{Cd}, \mathrm{Pb}$ and $\mathrm{Ni}$ were considerably higher in the shell or hard tissue. Yap et al. [26] found that shell of $P$. viridis can be a potential biomonitoring material for $\mathrm{Cd}, \mathrm{Pb}$ and $\mathrm{Zn}$.

However in this study carapace shows the highest accumulation of $\mathrm{Fe}$, ranging from 43.46- 75.17 $\mu \mathrm{g} / \mathrm{g} \mathrm{dw}$. Meanwhile for $\mathrm{Cd}$, accumulation in the carapace ranged from $0.63-0.79 \mu \mathrm{g} / \mathrm{g} \mathrm{dw}$. This may be due to the composition of the carapace being not similar to that of bivalve shells. The other hard tissues namely the telson and leg showed similar patterns as the carapace.
The Fe concentrations in the leg ranged from 158.40- $209.30 \mu \mathrm{g} / \mathrm{g} \mathrm{dw}$ whereas for telson, the concentrations of Fe ranged from 29.87- $86.39 \mu \mathrm{g} / \mathrm{g}$ $\mathrm{dw}$. In contrast, concentrations of $\mathrm{Cd}$ in leg and telson ranged from $0.61-0.93 \mu \mathrm{g} / \mathrm{g} \mathrm{dw}$ and $0.76-$ $1.19 \mu \mathrm{g} / \mathrm{g} \mathrm{dw}$ respectively. Itow et al. [10] reported that elevated levels of $\mathrm{Cd}$ could inhibit the regeneration of walking legs in horseshoe crabs.

Besides the muscles, the $\mathrm{Pb}$ and $\mathrm{Ni}$ concentrations in eggs of horseshoe crabs from the Juru River are again higher than those from the Sepang Besar River. The present finding proved that the Juru River and its vicinity is contaminated by high levels of heavy metals and this could due to its proximity to the Prai Industrial Estate [27]. Many studies in horseshoe crabs focused on the heavy metals in the eggs.

This was due to two reasons: (1) the development of the horseshoe crab themselves might be affected, and (2) vulnerable populations of shorebirds might receive a high dose of heavy metals during a critical migratory period when they must double their weight [28-30].

Itow et al. [10] stated that horseshoe crab eggs can accumulate heavy metals, with $\mathrm{Hg}$, organotin, and $\mathrm{Cd}$ being the most toxic.

Biota-sediment accumulation factors (BSAF) have been proposed as a simple model for predicting the bioaccumulation of sediment-associated contaminants by infaunal invertebrates [8]. BSAF can be estimated based on the metal concentrations in the horseshoe crabs divided by the metal concentrations in the sediment, basically using the formula $\mathrm{BSAF}=$ horseshoe $\mathrm{crab} \mathrm{dw} /$ Sediment $\mathrm{dw}$.

In this study, BSAF is based on metal concentrations in the muscle tissue with the total metal concentrations of the sediment. The BSAF values from this study are presented in Table 11 . The BSAF values are in the range of $0.40-3.73$ for $\mathrm{Cd}, 1.36-2.50$ for $\mathrm{Cu}, 0.00-0.01$ for $\mathrm{Fe}, 0.20-0.32$ for $\mathrm{Ni}, 0.13-0.40$ for $\mathrm{Pb}$ and $0.89-2.68$ for $\mathrm{Zn}$. The greater bioaccumulation potential of $\mathrm{Cd}, \mathrm{Cu}$ and $\mathrm{Zn}$ by $T$. gigas should be interpreted carefully and should prompt more future studies.

These results imply the specific bioaccumulation of $\mathrm{Cd}, \mathrm{Cu}$ and $\mathrm{Zn}$ in T. gigas. On the other hand, lower $\mathrm{BSAF}$ values of $\mathrm{Fe}, \mathrm{Ni}$ and $\mathrm{Pb}$ are found. 
Table 4: The mean concentrations ( $\mu \mathrm{g} / \mathrm{g}$ dry weight) of $\mathrm{Cd}$ in different parts; carapace, leg, telson, muscle, gill, operculum and egg of Tachypleus gigas from Juru River 1, Juru River 2 and Sepang River.

\begin{tabular}{|c|c|c|c|c|c|c|c|}
\hline Location & Sex & $\mathrm{N}$ & Part & Mean & SE & Min & Max \\
\hline \multirow[t]{13}{*}{ Juru River 1} & \multirow[t]{6}{*}{ Male } & 4 & Carapace & 0.79 & 0.08 & 0.68 & 0.95 \\
\hline & & 4 & Leg & 0.88 & 0.13 & 0.72 & 1.16 \\
\hline & & 4 & Telson & 0.76 & 0.16 & 0.52 & 1.07 \\
\hline & & 4 & Muscle & 0.96 & 0.03 & 0.91 & 1.03 \\
\hline & & 4 & Gill & 1.31 & 0.18 & 1.07 & 1.67 \\
\hline & & 4 & Operculum & 1.29 & 0.13 & 1.15 & 1.43 \\
\hline & \multirow[t]{7}{*}{ Female } & 1 & Carapace & 0.73 & 0.12 & 0.52 & 0.95 \\
\hline & & 1 & Leg & 0.93 & 0.06 & 0.87 & 1.00 \\
\hline & & 1 & Telson & 0.83 & 0.08 & 0.75 & 0.92 \\
\hline & & 1 & Muscle & 1.05 & 0.02 & 1.03 & 1.07 \\
\hline & & 1 & Gill & 1.15 & 0.02 & 1.12 & 1.20 \\
\hline & & 1 & Operculum & 1.15 & 0.08 & 1.08 & 1.24 \\
\hline & & 1 & Egg & 1.34 & 0.06 & 1.27 & 1.47 \\
\hline \multirow[t]{13}{*}{ Juru River 2} & \multirow[t]{6}{*}{ Male } & 3 & Carapace & 0.63 & 0.06 & 0.56 & 0.75 \\
\hline & & 3 & Leg & 0.74 & 0.04 & 0.68 & 0.84 \\
\hline & & 3 & Telson & 0.92 & 0.05 & 0.83 & 1.03 \\
\hline & & 3 & Muscle & 1.12 & 0.10 & 0.96 & 1.31 \\
\hline & & 3 & Gill & 1.65 & 0.08 & 1.50 & 1.78 \\
\hline & & 3 & Operculum & 1.41 & 0.01 & 1.39 & 1.43 \\
\hline & \multirow[t]{7}{*}{ Female } & 2 & Carapace & 0.65 & 0.06 & 0.59 & 0.71 \\
\hline & & 2 & Leg & 0.91 & 0.04 & 0.84 & 0.99 \\
\hline & & 2 & Telson & 1.19 & 0.03 & 1.15 & 1.23 \\
\hline & & 2 & Muscle & 1.53 & 0.08 & 1.43 & 1.71 \\
\hline & & 2 & Gill & 1.65 & 0.13 & 1.51 & 1.79 \\
\hline & & 2 & Operculum & 1.81 & 0.01 & 1.40 & 1.43 \\
\hline & & 2 & Egg & 1.93 & 0.11 & 1.75 & 2.15 \\
\hline \multirow[t]{7}{*}{ Sepang Besar River } & \multirow[t]{7}{*}{ Female } & 2 & Carapace & 0.68 & 0.10 & 0.51 & 0.87 \\
\hline & & 2 & Leg & 0.61 & 0.16 & 0.36 & 0.92 \\
\hline & & 2 & Telson & 0.99 & 0.08 & 0.83 & 1.11 \\
\hline & & 2 & Muscle & 1.46 & 0.24 & 1.15 & 1.94 \\
\hline & & 2 & Gill & 1.57 & 0.13 & 1.35 & 1.83 \\
\hline & & 2 & Operculum & 1.60 & 0.10 & 1.39 & 1.74 \\
\hline & & 2 & Egg & 1.22 & 0.26 & 1.91 & 2.74 \\
\hline
\end{tabular}

Note: $\mathrm{N}$ represent the number of individuals analyzed. 
Table 5: The mean concentrations ( $\mu \mathrm{g} / \mathrm{g}$ dry weight) of $\mathrm{Cu}$ in different parts; carapace, leg, telson, muscle, gill, operculum and egg of Tachypleus gigas from Juru River 1, Juru River 2 and Sepang River.

\begin{tabular}{|c|c|c|c|c|c|c|c|}
\hline Location & Sex & $\mathrm{N}$ & Part & Mean & SE & Min & Max \\
\hline \multirow[t]{13}{*}{ Juru River 1} & Male & 4 & Carapace & 4.35 & 0.56 & 3.61 & 5.47 \\
\hline & & 4 & Leg & 71.82 & 5.22 & 63.40 & 81.40 \\
\hline & & 4 & Telson & 15.53 & 0.52 & 14.49 & 16.08 \\
\hline & & 4 & Muscle & 91.63 & 7.17 & 77.87 & 102.04 \\
\hline & & 4 & Gill & 193.22 & 10.20 & 178.43 & 212.79 \\
\hline & & 4 & Operculum & 125.50 & 2.86 & 122.64 & 128.38 \\
\hline & Female & 1 & Carapace & 2.65 & 0.166 & 2.34 & 2.90 \\
\hline & & 1 & Leg & 49.20 & 0.06 & 19.14 & 19.27 \\
\hline & & 1 & Telson & 11.74 & 0.14 & 11.60 & 11.88 \\
\hline & & 1 & Muscle & 128.65 & 7.66 & 120.99 & 136.31 \\
\hline & & 1 & Gill & 93.81 & 4.46 & 86.21 & 101.66 \\
\hline & & 1 & Operculum & 94.99 & 1.85 & 93.14 & 96.85 \\
\hline & & 1 & Egg & 199.82 & 4.78 & 192.13 & 208.60 \\
\hline \multirow[t]{13}{*}{ Juru River 2} & Male & 3 & Carapace & 8.56 & 1.15 & 6.83 & 10.75 \\
\hline & & 3 & Leg & 74.63 & 2.01 & 70.88 & 77.79 \\
\hline & & 3 & Telson & 24.31 & 0.08 & 24.22 & 24.48 \\
\hline & & 3 & Muscle & 137.86 & 9.72 & 118.46 & 148.69 \\
\hline & & 3 & Gill & 240.29 & 13.43 & 216.62 & 263.12 \\
\hline & & 3 & Operculum & 133.95 & 0.98 & 132.96 & 134.94 \\
\hline & Female & 2 & Carapace & 3.04 & 0.18 & 2.86 & 3.24 \\
\hline & & 2 & Leg & 49.19 & 4.60 & 42.24 & 57.91 \\
\hline & & 2 & Telson & 13.71 & 1.16 & 12.54 & 14.88 \\
\hline & & 2 & Muscle & 86.87 & 3.18 & 82.68 & 93.13 \\
\hline & & 2 & Gill & 139.52 & 3.61 & 135.91 & 143.14 \\
\hline & & 2 & Operculum & 66.93 & 6.58 & 60.35 & 73.52 \\
\hline & & 2 & Egg & 117.27 & 0.80 & 116.19 & 118.84 \\
\hline \multirow[t]{7}{*}{ Sepang Besar River } & Female & 2 & Carapace & 1.97 & 0.18 & 1.71 & 2.34 \\
\hline & & 2 & Leg & 42.33 & 2.76 & 39.09 & 47.83 \\
\hline & & 2 & Telson & 10.23 & 2.07 & 6.12 & 12.73 \\
\hline & & 2 & Muscle & 38.23 & 2.31 & 33.80 & 41.60 \\
\hline & & 2 & Gill & 102.85 & 7.29 & 88.78 & 113.22 \\
\hline & & 2 & Operculum & 68.25 & 2.69 & 65.32 & 73.63 \\
\hline & & 2 & Egg & 111.71 & 0.53 & 111.09 & 112.77 \\
\hline
\end{tabular}

Note: $\mathrm{N}$ represent the number of individuals analyzed. 
Table 6: The mean concentrations ( $\mu \mathrm{g} / \mathrm{g}$ dry weight) of Fe in different parts; carapace, leg, telson, muscle, gill, operculum and egg of Tachypleus gigas from Juru River 1, Juru River 2 and Sepang River.

\begin{tabular}{|c|c|c|c|c|c|c|c|}
\hline Location & Sex & $\mathrm{N}$ & Part & Mean & SE & Min & Max \\
\hline \multirow[t]{13}{*}{ Juru River 1} & Male & 4 & Carapace & 73.17 & 6.74 & 59.68 & 80.11 \\
\hline & & 4 & Leg & 209.30 & 8.08 & 193.39 & 219.70 \\
\hline & & 4 & Telson & 20.45 & 0.36 & 19.74 & 20.90 \\
\hline & & 4 & Muscle & 238.67 & 1.77 & 236.13 & 242.10 \\
\hline & & 4 & Gill & 915.08 & 17.14 & 892.77 & 948.79 \\
\hline & & 4 & Operculum & 435.57 & 4.27 & 431.29 & 439.85 \\
\hline & Female & 1 & Carapace & 43.46 & 1.38 & 41.12 & 45.93 \\
\hline & & 1 & Leg & 172.53 & 6.64 & 165.89 & 179.18 \\
\hline & & 1 & Telson & 36.96 & 4.51 & 32.45 & 41.48 \\
\hline & & 1 & Muscle & 130.19 & 4.89 & 125.30 & 135.08 \\
\hline & & 1 & Gill & 795.60 & 3.03 & 789.86 & 800.16 \\
\hline & & 1 & Operculum & 323.51 & 5.74 & 317.77 & 329.27 \\
\hline & & 1 & Egg & 69.23 & 2.55 & 64.37 & 73.05 \\
\hline \multirow[t]{13}{*}{ Juru River 2} & Male & 3 & Carapace & 65.35 & 4.72 & 58.45 & 74.40 \\
\hline & & 3 & Leg & 158.40 & 11.64 & 138.22 & 178.55 \\
\hline & & 3 & Telson & 43.04 & 3.33 & 36.75 & 48.13 \\
\hline & & 3 & Muscle & 132.99 & 5.56 & 122.03 & 140.16 \\
\hline & & 3 & Gill & 786.75 & 7.45 & 772.12 & 796.53 \\
\hline & & 3 & Operculum & 244.47 & 7.01 & 237.46 & 251.49 \\
\hline & Female & 2 & Carapace & 75.17 & 2.01 & 73.16 & 77.19 \\
\hline & & 2 & Leg & 170.65 & 12.84 & 147.56 & 191.97 \\
\hline & & 2 & Telson & 85.78 & 10.43 & 75.35 & 96.22 \\
\hline & & 2 & Muscle & 159.19 & 5.19 & 149.32 & 166.91 \\
\hline & & 2 & Gill & 961.19 & 14.13 & 947.05 & 975.33 \\
\hline & & 2 & Operculum & 358.47 & 6.53 & 351.94 & 365.02 \\
\hline & & 2 & Egg & 74.02 & 5.12 & 64.50 & 82.06 \\
\hline \multirow{7}{*}{$\begin{array}{l}\text { Sepang } \\
\text { River }\end{array}$} & Female & 2 & Carapace & 63.69 & 3.88 & 55.93 & 67.95 \\
\hline & & 2 & Leg & 205.29 & 14.28 & 186.10 & 233.21 \\
\hline & & 2 & Telson & 29.87 & 4.04 & 24.89 & 37.89 \\
\hline & & 2 & Muscle & 111.38 & 4.48 & 163.87 & 179.37 \\
\hline & & 2 & Gill & 845.91 & 13.87 & 819.09 & 865.45 \\
\hline & & 2 & Operculum & 386.82 & 5.67 & 376.86 & 396.51 \\
\hline & & 2 & Egg & 51.37 & 1.86 & 48.53 & 54.89 \\
\hline
\end{tabular}

Note: $\mathrm{N}$ represent the number of individuals analyzed. 
Table 7: The mean concentrations ( $\mu \mathrm{g} / \mathrm{g}$ dry weight) of Ni in different parts; carapace, leg, telson, muscle, gill, operculum and egg of Tachypleus gigas from Juru River 1, Juru River 2 and Sepang River.

\begin{tabular}{|c|c|c|c|c|c|c|c|c|}
\hline Location & & Sex & $\mathrm{N}$ & Part & Mean & SE & Min & Max \\
\hline \multirow{13}{*}{\multicolumn{2}{|c|}{ Juru River 1}} & \multirow[t]{6}{*}{ Male } & 4 & Carapace & 1.90 & 0.28 & 1.35 & 2.30 \\
\hline & & & 4 & Leg & 2.89 & 0.29 & 2.55 & 3.47 \\
\hline & & & 4 & Telson & 5.74 & 0.21 & 1.39 & 2.13 \\
\hline & & & 4 & Muscle & 8.84 & 0.12 & 2.66 & 3.07 \\
\hline & & & 4 & Gill & 6.10 & 0.25 & 5.70 & 6.57 \\
\hline & & & 4 & Operculum & 3.89 & 0.27 & 3.62 & 4.17 \\
\hline & & \multirow[t]{7}{*}{ Female } & 1 & Carapace & 4.73 & 0.25 & 4.24 & 5.08 \\
\hline & & & 1 & Leg & 8.72 & 0.94 & 7.78 & 9.68 \\
\hline & & & 1 & Telson & 6.52 & 0.82 & 5.70 & 7.35 \\
\hline & & & 1 & Muscle & 9.11 & 0.44 & 8.67 & 9.56 \\
\hline & & & 1 & Gill & 11.12 & 0.63 & 9.86 & 11.89 \\
\hline & & & 1 & Operculum & 9.46 & 0.82 & 8.65 & 10.29 \\
\hline & & & 1 & Egg & 7.48 & 0.58 & 6.62 & 8.60 \\
\hline \multirow{13}{*}{\multicolumn{2}{|c|}{ Juru River 2}} & \multirow[t]{6}{*}{ Male } & 3 & Carapace & 5.21 & 0.36 & 4.60 & 5.88 \\
\hline & & & 3 & Leg & 6.95 & 0.28 & 6.43 & 7.43 \\
\hline & & & 3 & Telson & 6.57 & 0.51 & 5.57 & 7.30 \\
\hline & & & 3 & Muscle & 8.24 & 0.33 & 7.60 & 8.75 \\
\hline & & & 3 & Gill & 8.74 & 0.76 & 7.36 & 9.99 \\
\hline & & & 3 & Operculum & 8.03 & 0.19 & 7.84 & 8.23 \\
\hline & & \multirow[t]{7}{*}{ Female } & 2 & Carapace & 2.77 & 0.52 & 2.25 & 3.29 \\
\hline & & & 2 & Leg & 6.15 & 0.17 & 5.97 & 6.50 \\
\hline & & & 2 & Telson & 5.12 & 0.23 & 4.89 & 5.36 \\
\hline & & & 2 & Muscle & 6.49 & 0.27 & 6.21 & 7.05 \\
\hline & & & 2 & Gill & 9.09 & 0.02 & 9.07 & 9.12 \\
\hline & & & 2 & Operculum & 7.37 & 0.12 & 7.24 & 7.50 \\
\hline & & & 2 & Egg & 7.59 & 0.39 & 6.80 & 8.09 \\
\hline \multirow{7}{*}{$\begin{array}{l}\text { Sepang } \\
\text { River }\end{array}$} & \multirow[t]{7}{*}{ Besar } & \multirow[t]{7}{*}{ Female } & 2 & Carapace & 2.99 & 0.10 & 2.86 & 3.21 \\
\hline & & & 2 & Leg & 6.86 & 0.37 & 6.12 & 7.37 \\
\hline & & & 2 & Telson & 5.94 & 0.18 & 5.71 & 6.32 \\
\hline & & & 2 & Muscle & 5.22 & 0.08 & 8.07 & 8.36 \\
\hline & & & 2 & Gill & 8.79 & 0.39 & 8.15 & 9.51 \\
\hline & & & 2 & Operculum & 8.57 & 0.27 & 8.12 & 9.07 \\
\hline & & & 2 & Egg & 6.72 & 0.51 & 5.73 & 7.47 \\
\hline
\end{tabular}

Note: $\mathrm{N}$ represent the number of individuals analyzed. 
Table 8: The mean concentrations ( $\mu \mathrm{g} / \mathrm{g}$ dry weight) of $\mathrm{Pb}$ in different parts; carapace, leg, telson, muscle, gill, operculum and egg of Tachypleus gigas from Juru River 1, Juru River 2 and Sepang River.

\begin{tabular}{|c|c|c|c|c|c|c|c|}
\hline Location & Sex & $\mathrm{N}$ & Part & Mean & SE & Min & Max \\
\hline \multirow[t]{13}{*}{ Juru River 1} & Male & 4 & Carapace & 5.57 & 0.46 & 4.67 & 6.08 \\
\hline & & 4 & Leg & 6.40 & 0.60 & 5.42 & 7.49 \\
\hline & & 4 & Telson & 7.67 & 0.37 & 6.95 & 8.23 \\
\hline & & 4 & Muscle & 12.97 & 0.73 & 11.85 & 14.35 \\
\hline & & 4 & Gill & 14.17 & 0.06 & 14.09 & 14.31 \\
\hline & & 4 & Operculum & 10.80 & 0.08 & 10.72 & 10.90 \\
\hline & Female & 1 & Carapace & 7.01 & 0.38 & 6.27 & 7.55 \\
\hline & & 1 & Leg & 5.42 & 0.01 & 5.42 & 5.44 \\
\hline & & 1 & Telson & 5.57 & 0.18 & 5.38 & 5.76 \\
\hline & & 1 & Muscle & 7.96 & 0.73 & 7.23 & 8.71 \\
\hline & & 1 & Gill & 11.56 & 0.42 & 10.87 & 12.33 \\
\hline & & 1 & Operculum & 9.52 & 0.67 & 8.85 & 10.20 \\
\hline & & 1 & Egg & 11.26 & 0.22 & 10.82 & 11.57 \\
\hline \multirow[t]{13}{*}{ Juru River 2} & Male & 3 & Carapace & 10.18 & 1.04 & 8.70 & 12.21 \\
\hline & & 3 & Leg & 10.98 & 0.97 & 9.06 & 12.23 \\
\hline & & 3 & Telson & 14.03 & 0.89 & 12.26 & 15.14 \\
\hline & & 3 & Muscle & 15.67 & 0.05 & 15.60 & 15.79 \\
\hline & & 3 & Gill & 17.44 & 0.66 & 16.16 & 18.35 \\
\hline & & 3 & Operculum & 15.43 & 0.90 & 14.52 & 16.34 \\
\hline & Female & 2 & Carapace & 4.15 & 0.10 & 4.05 & 4.26 \\
\hline & & 2 & Leg & 6.48 & 0.58 & 5.73 & 7.65 \\
\hline & & 2 & Telson & 6.27 & 0.88 & 5.40 & 7.16 \\
\hline & & 2 & Muscle & 8.69 & 0.03 & 8.64 & 8.77 \\
\hline & & 2 & Gill & 10.68 & 0.42 & 10.27 & 11.11 \\
\hline & & 2 & Operculum & 9.22 & 0.68 & 8.54 & 9.91 \\
\hline & & 2 & Egg & 9.44 & 0.49 & 8.72 & 10.40 \\
\hline \multirow{7}{*}{$\begin{array}{l}\text { Sepang } \\
\text { River }\end{array}$} & Female & 2 & Carapace & 3.19 & 0.26 & 2.69 & 3.58 \\
\hline & & 2 & Leg & 5.02 & 0.75 & 3.81 & 6.41 \\
\hline & & 2 & Telson & 3.32 & 0.24 & 2.86 & 3.67 \\
\hline & & 2 & Muscle & 5.39 & 0.88 & 4.12 & 7.09 \\
\hline & & 2 & Gill & 10.36 & 0.39 & 9.43 & 11.01 \\
\hline & & 2 & Operculum & 7.28 & 0.31 & 6.69 & 7.76 \\
\hline & & 2 & Egg & 7.96 & 0.47 & 7.03 & 8.59 \\
\hline
\end{tabular}

Note: $\mathrm{N}$ represent the number of individuals analyzed. 
Table 9: The mean concentrations ( $\mu \mathrm{g} / \mathrm{g}$ dry weight) of $\mathrm{Zn}$ in different parts; carapace, leg, telson, muscle, gill, operculum and egg of Tachypleus gigas from Juru River 1, Juru River 2 and Sepang River.

\begin{tabular}{|c|c|c|c|c|c|c|c|}
\hline Location & Sex & $\mathrm{N}$ & Part & Mean & $\mathrm{SE}$ & Min & Max \\
\hline \multirow[t]{13}{*}{ Juru River 1} & Male & 4 & Carapace & 25.52 & 0.66 & 24.19 & 26.25 \\
\hline & & 4 & Leg & 137.16 & 8.26 & 127.32 & 153.58 \\
\hline & & 4 & Telson & 20.45 & 0.36 & 19.74 & 20.90 \\
\hline & & 4 & Muscle & 238.67 & 1.77 & 236.13 & 242.10 \\
\hline & & 4 & Gill & 141.48 & 7.01 & 133.19 & 155.41 \\
\hline & & 4 & Operculum & 103.41 & 15.21 & 88.20 & 118.63 \\
\hline & Female & 1 & Carapace & 17.76 & 0.73 & 16.70 & 19.18 \\
\hline & & 1 & Leg & 136.77 & 16.52 & 120.25 & 153.29 \\
\hline & & 1 & Telson & 26.16 & 2.43 & 23.73 & 28.60 \\
\hline & & 1 & Muscle & 254.85 & 6.99 & 247.86 & 261.86 \\
\hline & & 1 & Gill & 113.79 & 0.91 & 112.49 & 115.56 \\
\hline & & 1 & Operculum & 107.41 & 2.18 & 105.22 & 109.60 \\
\hline & & 1 & Egg & 144.35 & 3.31 & 137.89 & 148.85 \\
\hline \multirow[t]{13}{*}{ Juru River 2} & Male & 3 & Carapace & 19.55 & 2.47 & 15.90 & 24.28 \\
\hline & & 3 & Leg & 70.11 & 3.56 & 64.97 & 76.96 \\
\hline & & 3 & Telson & 15.02 & 0.35 & 14.35 & 15.57 \\
\hline & & 3 & Muscle & 255.61 & 9.66 & 236.54 & 267.86 \\
\hline & & 3 & Gill & 90.84 & 3.11 & 84.78 & 95.15 \\
\hline & & 3 & Operculum & 82.49 & 0.04 & 82.45 & 82.54 \\
\hline & Female 2 & 2 & Carapace & 19.08 & 1.99 & 17.09 & 21.08 \\
\hline & & 2 & Leg & 106.03 & 6.04 & 98.59 & 117.99 \\
\hline & & 2 & Telson & 21.63 & 2.38 & 19.25 & 24.02 \\
\hline & & 2 & Muscle & 240.80 & 3.78 & 236.37 & 248.33 \\
\hline & & 2 & Gill & 102.60 & 1.05 & 101.55 & 103.66 \\
\hline & & 2 & Operculum & 102.47 & 10.88 & 91.59 & 113.36 \\
\hline & & 2 & Egg & 134.27 & 1.37 & 131.57 & 136.00 \\
\hline \multirow{7}{*}{$\begin{array}{l}\text { Sepang } \\
\text { River }\end{array}$} & Female & 2 & Carapace & 10.16 & 1.47 & 8.23 & 13.06 \\
\hline & & 2 & Leg & 80.72 & 4.74 & 72.76 & 89.19 \\
\hline & & 2 & Telson & 7.25 & 0.56 & 6.12 & 7.85 \\
\hline & & 2 & Muscle & 236.42 & 4.17 & 231.58 & 244.73 \\
\hline & & 2 & Gill & 103.03 & 2.53 & 98.21 & 106.77 \\
\hline & & 2 & Operculum & 93.49 & 4.31 & 88.85 & 102.13 \\
\hline & & 2 & Egg & 122.84 & 0.38 & 122.12 & 123.41 \\
\hline
\end{tabular}


Malaysian Journal of Science 29 (2): 137-152 (2010)

Table 10: Concentrations $(\mu \mathrm{g} / \mathrm{g}$ dry weight $\pm \mathrm{SE}$ ) of $\mathrm{Cd}, \mathrm{Cu}, \mathrm{Fe}, \mathrm{Pb}, \mathrm{Ni}$ and $\mathrm{Zn}$ in the surface sediments collected from the Juru River and the Sepang Besar River (SBR).

\begin{tabular}{|c|c|c|c|c|c|c|c|}
\hline $\begin{array}{l}\text { Digestions/ } \\
\text { Heavy Metals }\end{array}$ & Sites & $\mathrm{Cd}$ & $\mathrm{Cu}$ & $\mathrm{Fe}$ & $\mathrm{Ni}$ & $\mathrm{Pb}$ & $\mathrm{Zn}$ \\
\hline \multirow{4}{*}{$\begin{array}{l}\text { Total } \\
\text { concentration }\end{array}$} & Juru & $0.41 \pm$ & $63.81 \pm 0.56$ & $27906 \pm 450$ & $32.74 \pm 0.29$ & $38.83 \pm$ & $269 \pm 0.41$ \\
\hline & & 0.06 & & & & 0.43 & \\
\hline & SBR & 3.68 & $15.28 \quad \pm$ & 32489 & $16.10 \pm 0.63$ & $41.25 \pm$ & $88.3 \pm 4.91$ \\
\hline & & \pm 0.12 & 0.19 & 2753 & & 0.84 & \\
\hline \multirow[t]{4}{*}{ Sum of SET } & Juru & $1.02 \pm$ & $74.59 \pm$ & $34535 \pm 410$ & $40.46 \pm 0.38$ & $35.09 \pm$ & $270 \pm 3.34$ \\
\hline & & 0.14 & 0.62 & & & 0.56 & \\
\hline & SBR & 3.07 & $16.12 \pm$ & 29071 & $15.39 \pm 0.40$ & $37.68 \pm$ & 106.15 \\
\hline & & \pm 0.00 & 0.65 & 1081 & & 0.04 & 2.45 \\
\hline \multirow[t]{4}{*}{ EFLE } & Juru & $0.20 \pm$ & $2.38 \pm 0.02$ & $202 \pm 15.0$ & $2.44 \pm 0.26$ & $0.62 \pm$ & $51.84 \pm 0.48$ \\
\hline & & 0.12 & & & & 0.16 & \\
\hline & SBR & 0.43 & $0.05 \pm 0.03$ & $816 \pm 27.0$ & $0.53 \pm 0.13$ & $1.72 \pm$ & $1.55 \pm 0.08$ \\
\hline & & \pm 0.02 & & & & 0.12 & \\
\hline \multirow{4}{*}{$\begin{array}{l}\text { Acid- } \\
\text { reducible }\end{array}$} & Juru & $0.15 \pm$ & $0.10 \pm 0.03$ & $600 \pm 52.0$ & $3.42 \pm 0.12$ & $0.53 \pm$ & $61.88 \pm 0.79$ \\
\hline & & 0.03 & & & & 0.12 & \\
\hline & SBR & 0.03 & $0.13 \pm 0.02$ & $1451 \pm 251$ & $0.28 \pm 0.03$ & $1.39 \pm$ & $19.08 \pm 2.00$ \\
\hline & & \pm 0.01 & & & & 0.20 & \\
\hline \multirow{4}{*}{$\begin{array}{l}\text { Oxidisable- } \\
\text { organic }\end{array}$} & Juru & $0.05 \pm$ & $16.89 \pm$ & $4581 \pm 285$ & $19.72 \pm 0.36$ & $22.83 \pm$ & $84.98 \pm 1.45$ \\
\hline & & 0.00 & 0.55 & & & 0.29 & \\
\hline & SBR & 0.01 & $4.47 \pm 0.00$ & $6380 \pm 140$ & $6.06 \pm 0.48$ & $11.12 \pm$ & $43.83 \pm 2.61$ \\
\hline & & \pm 0.00 & & & & 0.19 & \\
\hline \multirow[t]{4}{*}{ Resistant } & Juru & $0.62 \pm$ & $55.22 \pm$ & $29152 \pm 629$ & $14.87 \pm 0.36$ & $11.12 \pm$ & $71.34 \pm 0.61$ \\
\hline & & 0.06 & 0.03 & & & 0.80 & \\
\hline & SBR & 2.59 & $11.46 \pm$ & 20424 & $8.54 \pm 0.18$ & $23.45 \pm$ & $41.68 \pm 1.76$ \\
\hline & & \pm 0.00 & 0.70 & 1166 & & 0.17 & \\
\hline
\end{tabular}

Note: Sum of SET= Summation of EFLE, Acid-reducible, Oxidisable-organic and resistant fractions. 
Table 11: Biota-sediment accumulation factors (BSAF) based on the muscles of Tachypleus gigas.

\begin{tabular}{llllllll}
\hline Location & Sex & $\mathrm{Cd}$ & $\mathrm{Cu}$ & $\mathrm{Fe}$ & $\mathrm{Ni}$ & $\mathrm{Pb}$ & $\mathrm{Zn}$ \\
\hline Juru River 1 & Male & 2.34 & 1.44 & 0.01 & 0.27 & 0.33 & 0.89 \\
& Female & 2.56 & 2.02 & 0.00 & 0.28 & 0.20 & 0.95 \\
& & & & & & & \\
Juru River 2 & Male & 2.73 & 2.16 & 0.00 & 0.25 & 0.40 & 0.95 \\
& Female & 3.73 & 1.36 & 0.01 & 0.20 & 0.22 & 0.90 \\
& & & & & & & \\
Sepang Besar & Female & 0.40 & 2.50 & 0.00 & 0.32 & 0.13 & \\
River & & & & & & & \\
\hline
\end{tabular}

\section{CONCLUSIONS}

The most significant finding of present study is that the muscle of $T$. gigas is a potential biomonitoring organ of $\mathrm{Cu}, \mathrm{Ni}$ and $\mathrm{Zn}$. This is due to higher levels of these metals being found in horseshoe crabs from the polluted Juru River than in those from the relatively unpolluted Sepang Besar River.

Since this finding is well supported by the sediment data, the use of the muscle of T. gigas as a biomonitor of $\mathrm{Cu}, \mathrm{Ni}$ and $\mathrm{Zn}$ contaminations and bioavailabilities of the sampling sites, is therefore proposed for future biomonitoring studies.

\section{ACKNOWLEDGEMENT}

The authors wish to thank the Research University Grant Scheme (RUGS), [Pusat Kos: 91986], provided by Universiti Putra Malaysia which funded this study.

\section{REFERENCES}

1. Shuster C. N. (1985). Introductory remarks on the distribution and abundance of the American horseshoe crab, Limulus polyphemus, spawning in the Chesapeake Bay area. In: Proceedings from the Chesapeake Bay Symposium. (eds. Chase V.) Baltimore, MD, pp. 34-38.

2. Sekiguchi K. and Nakamura K. (1979). Ecology of the extant horseshoe crabs. Progress in Clinical and Biological Research 29: 37-45.
3. Chatterji A., Mishra J.K. and Parulekar A.H. (1992). Feeding behaviour and food selection in the horseshoe crab, Tachypleus gigas (Muller). Hydrobiologia 246: 41-18.

4. Kungsuwan A., Nagashima Y., Noguchi T., Shida Y., Suvapeepan S., Suwansakornkul P. and Hashimoto K. (1981). Tetrodotoxin in the eggs of horseshoe crab, Carcinoscorpius rotundicauda inhabiting Thailand. Progress in Venom Research and Toxin Research, pp 470474.

5. Chiu H.M.C. and Morton B. (1999). The distribution of horseshoe crabs (Tachypleus tridentatus and Carcinoscorpius rotundicauda) in Hong Kong. Asian Marine Biology 16: 185194.

6. Sekiguchi K., Nakamura K., Sen T.K. and Sugita H. (1976). Morphological variation and distribution of a horseshoe crab, Tachypleus gigas, from the Bay of Bengal and Gulf of Siam. Proceedings of the Japanese Society of Systematic Zoology 12: 13-20.

7. Burger J. and Gochfeld M. (1995). Heavy metal and selenium concentrations in eggs of herring gulls (Larus argentatus): temporal differences from 1989 to 1994. Archive of Environment Contamination and Toxicology 29: 192-197.

8. Kannan, K., Yasunaga, Y., Iwata, H., Ichihashi, H., Tanabe, S. and R. Tatsukawa. (1995). Concentrations of heavy metals, organochlorines, and organotins in horseshoe 
crab, Tachypleus tridentatus, from Japanase Coastal Waters. Environmental Contamination and Toxicology. 28: 40-47.

9. Botton M.L., Johnson K. and Helleby L. (1998). Effects of copper and zinc on embryos and larvae of the horseshoe crabs, Limulus Polyphemus. Archives Environmental Contamination Toxicology 64: 25-32.

10. Itow, T., Loveland, R.E. and M.L. Botton. (1998). Developmental abnormalities in horseshoe crab embryos caused by exposure to heavy metals. Environmental Contamination and Toxicology. 35: 33-40.

11. Botton M.L. (2000). Toxicity of cadmium and mercury to horseshoe crab (Limulus Polyphemus), embryos and larvae. Bulletin Environmental Contamination Toxicology 64: 137-143.

12. Burger J., Dixon C., Shukla T., Tsipoura N. and Gochfeld M. (2002). Metal levels in horseshoe crabs (Limulus polyphemus) from Maine to Florida. Environmental Research 90 (3): 227-236

13. Burger J., Dixon C., Shukla T., Tsipoura N., Jensen H., Fitzgerald M., Ramos R. and Gochfeld M. (2003). Metals in horseshoe crabs from Delaware Bay. Archives of Environmental Contamination and Toxicology 44 (1):36-42.

14. Mo C. and Neilson B. (1994). Standardization of oyster soft dry weight measurements. Water Research 28: 243 - 246.

15. Yap C.K., Ismail A., Tan S.G. and Omar H. (2002). Correlation between speciation of $\mathrm{Cd}$, $\mathrm{Cu}, \mathrm{Pb}$ and $\mathrm{Zn}$ in sediment and their concentrations in total soft tissue of greenlipped mussel Perna viridis from the west coast of Peninsular Malaysia. Environment International 28:117-126.

16. James, W.M. (1991). Inorganic contaminants of surface water- Research and monitoring priorities. Springer- Verlag. New York: USA. p. 64-321.

17. Department of Environment (2007). Final report on development of water quality and standards for Malaysia. Minisry of Natural Resources and Environment, Malaysia.

18. Kungsuwan A., Nagashima Y., Noguchi T., Shida Y., Suvapeepan S., Suwansakornkul P. and Hashimoto K. (1987). Tetrodotoxin in the horseshoe crab, Carcinoscorpius rotundicauda inhabiting Thailand. Nippon Suisan Gakkaishi 53: 261-266.

19. Burger J. (1997). Heavy metals in the eggs and muscle of horseshoe crabs (Limulus polyphemus) from Delaware Bay. Environmental and Monitoring Assessment 46: 279-287.

20. Burger J., Dixon C., Shukla T., Tsipoura N., Jensen H., Fitzgerald M., Ramos R. and Gochfeld M. (2003). Metals in Horseshoe Crabs from Delaware Bay. Archives of Environmental Contamination and Toxicology 44: 36-42.

21. Peakall D. B. (1992). Animal markers as pollution indicators, Chapman and Hall, London, England.

22. Fimreite N., Brevik F. M. and Torp R. (1982). Mercury and organochlorines in eggs from a Norwegian gannet colony. Bulletin Environment Contamination and Toxicology 28: 58-60.

23. Yap C. K., Ismail A., Edward F.B., Tan S. G. and Siraj S. S. (2006). Use of different soft tissues of Perna viridis as biomonitors of bioavailability and contamination by heavy metals $(\mathrm{Cd}, \mathrm{Cu}, \mathrm{Fe}, \mathrm{Pb}, \mathrm{Ni}$ and $\mathrm{Zn})$ in a semienclosed intertidal water, the Johore Straits. Toxicological and Environmental Chemistry 88(4): 683 - 695.

24. Burger J. (1992). Trace element levels in Pine Snake hatchlings: tissue and temporal differences. Archives Environmental Contamination Toxicology 22: 209-213.

25. Burger J. (1994). Heavy metals in avian eggshells: another excretion method. Journal Toxicology Environmental Health 41: 207220.

26. Yap C.K., Ismail A., Tan S.G. and Abdul Rahim I. (2003b). Can the shell of the greenlipped mussel Perna viridis from the west coast of Peninsular Malaysia be a potential biomonitoring material for $\mathrm{Cd}, \mathrm{Pb}$ and $\mathrm{Zn}$ ? Estuarine, Coastal and Shelf Science 57: 623630.

27. Yap, C.K. Ismail, A. and Tan, S.G. (2004). Heavy metal (Cd, $\mathrm{Cu}, \mathrm{Pb}$ and $\mathrm{Zn}$ ) concentrations in the green-lipped mussel Perna viridis (L.) collected from some wild and aquaculture sites in the west coast of Peninsular Malaysia. Food Chemistry 84: 569575. 
28. Castro G., Myers J.P. and Place A.R. (1989). Assimilation efficiency of sanderlings (Calidris alba) feeding on horseshoe crab eggs. Physiological Zoology 62: 716-731.

29. Castro G. and Myers J.P. (1993). Shorebird predation on eggs of horseshoe crabs during spring stopover on Delaware Bay. Auk 110: 927-930.
30. Tsipoura N. and Burger J. (1999). Shorebird diet during spring migration stop-over on Delaware Bay. Condor 101: 35-6 
Malaysian Journal of Science 29 (2): 137-152 (2010) 